\section{Financing Solar Installations with New Markets Tax Credits: Denver, Colorado}

\section{Third-Party Financing of Public Sector Solar Installations}

Solar energy installations in the public sector are commonly financed in partnership with third-party investors who can benefit from the available tax incentives as tax-paying entities. Traditionally the tax benefits have been the $30 \%$ investment tax credit (ITC) and accelerated depreciation. More recently, a 30\% cash grant from the U.S. Department of the Treasury has been used in place of the ITC. In addition, federal stimulus dollars are being directed toward thirdparty financed installations as well.

The latest addition to this practice of bundling incentives is New Markets Tax Credits (NMTCs). ${ }^{1}$ NMTCs are intended to attract investment into low income and disadvantaged neighborhoods, with the goal of encouraging greater economic activity and job creation. An investor in a Community Development Entity (CDE) will benefit from a 39\% federal tax credit over seven years, in addition to the actual returns on the investment itself. The CDE, in turn, uses this investment to make either equity investments or loans to qualified projects within the qualified neighborhoods.

\section{Denver's 1 Megawatt of Solar Installations}

The City of Denver, Colorado, is using NMTCs in an innovative transaction to install 1 megawatt (MW) of photovoltaics (PV) on a number of city buildings. The city is collaborating with solar developer Main Street Power (MSP) and two funds (Rose Urban Green [RUG] Fund and the Colorado Growth and Revitalization [CGR] Fund) managed by the Colorado Housing and Finance Authority (CHFA), to partner with U.S. Bancorp Community Development Corporation and Morgan Stanley on the project.

Currently, the city pays approximately $\$ 0.08-0.09$ per kilowatt-hour $(\mathrm{kWh})$ for its electricity, but half of this cost corresponds to demand charges. In order for a transaction to make economic sense for the city, a Power Purchase Agreement (PPA) price of $\$ 0.045 / \mathrm{kWh}$ or less was required. Using its NMTC allocations, both the CGR and RUG funds are providing low-cost loans to Main Street Power to finance

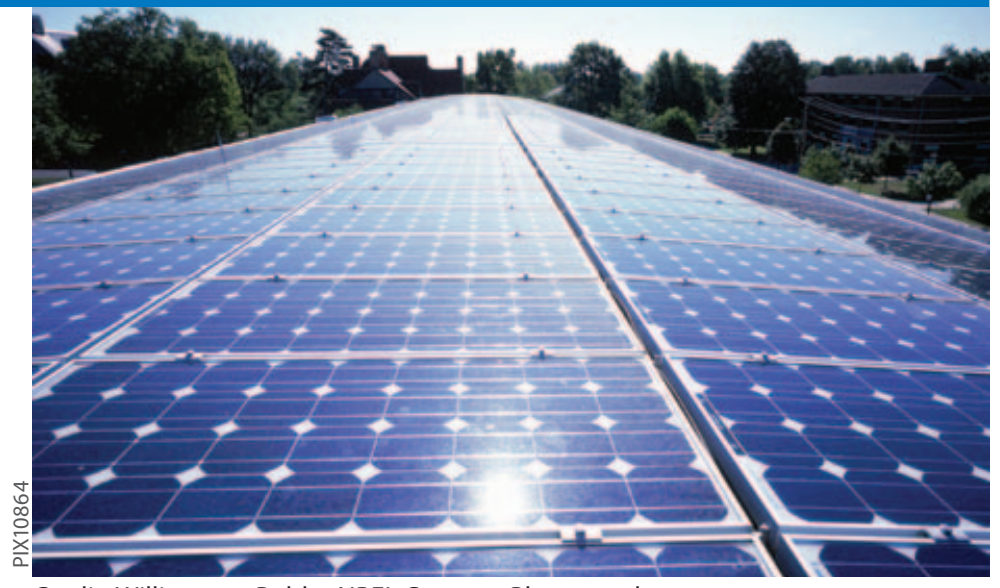

Credit: Williamson, Robb - NREL Contract Photographer.

the purchase and installation of the PV systems. MSP will own and operate the PV systems and sell electricity to the City of Denver under a PPA. As a result of the low-interest loans from the NMTC structure, MSP can offer a lower cost of electricity to the city than would otherwise be the case. MSP has calculated that the savings resulting from the lowcost loans alone equal \$.005 per kWh. These NMTC-related savings represent $25 \%$ of the total expected savings to the city over the life of the transaction. MSP is also benefitting from rebates and incentives from the local utility (Xcel Energy), the $30 \%$ U.S. Treasury grant, and accelerated depreciation.

\section{Denver's NMTC Project Details}

\begin{tabular}{|l|l|}
\hline Number of solar installations: & 13 (11 qualify for NMTC) \\
\hline Total installed capacity: & $1 \mathrm{MW}$ \\
\hline Length of PPA: & 20 years \\
\hline PPA price (year 1): & $<\$ 0.045 / \mathrm{kWh}$ \\
\hline $\begin{array}{l}\text { Annual rate that PPA price will } \\
\text { increase: }\end{array}$ & $<5 \% / \mathrm{yr}$ \\
\hline Upfront capital cost to the city: & $\mathbf{\$ 0}$ \\
\hline $\begin{array}{l}\text { Estimated savings to Denver over a } \\
\text { 20-year period: }\end{array}$ & $\mathbf{\$ 4 0 0 , 0 0 0}$ \\
\hline
\end{tabular}

\section{INREL}

National Renewable Energy Laboratory

1617 Cole Boulevard, Golden, Colorado 80401

303-275-3000 • www.nrel.gov

NREL/FS-7A2-49056 • September 2010

Printed with a renewable-source ink on paper containing at least $50 \%$ wastepaper, including $10 \%$ post consumer waste. 